\title{
HUBUNGAN PENGETAHUAN IBU TENTANG KESEHATAN REPRODUKSI REMAJA DENGAN UPAYA MEMPERSIAPKAN MASA PUBERTAS PADA ANAK DI SD NEGERI 20 PEKANBARU
}

\author{
${ }^{1)}$ Rini Hariani Ratih, ${ }^{2)}$ Sara Herlina ${ }^{3)}$ Yusmaharani \\ D-III Kebidanan, FKIK, Universitas Abdurrab \\ Jl. Riau Ujung No 73 Pekanbaru - Riau - Indonesia \\ E-mail : ${ }^{1)}$ rini.hariani.ratih@ univrab.ac.id ${ }^{2)}$ sara.herlina@ univrab.ac.id
}

\author{
Kata Kunci: \\ Pengetahuan ibu, kesehatan \\ reproduksi, pubertas
}

\begin{abstract}
ABSTRAK
Masa remaja adalah masa terjadinya pertumbuhan dan perkembangan yang cepat terutama fisik, psikologis serta intelektual. Remaja memiliki sifat khas yaitu rasa keingintahuan yang besar, menyukai petualangan dan tantangan serta cenderung berani menanggung resiko atas perbuatannya tanpa didahului oleh pertimbangan yang matang. Peran dan andil ibu sangat besar dalam masa melihat perkembangan anaknya untuk dapat melewati masa puberitasnya, karenaseorang ibu yang lebih banyak memperhatikan dan mengikuti perkembangan setiap anak-anaknya. Penelitian ini menggunakan jenis penelitian kuantitatif dengan metode analitik dan desain penelitian crossSectional yaitu penelitianuntuk melihat hubungan variabel independen den dependen. Tujuan dari penelitian yaitu Untuk mengetahui hubungan pengetahuan ibu tentang kesehatan reproduksi remaja dengan upaya mempersiapkan rnasapubertas pada anak di SD Negeri 20 Pekanbaru. Hasil dari penelitian yaitu Terdapat hubungan pengetahuan ibu tentang kesehatan reproduksi remaja dengan upaya mempersiapkan masa pubertas pada anak di SD Negerii 20 Pckanbaru dengan $\mathrm{P}_{\text {value }}-0,027$. Diharapkan kepada peneliti selanjutnya hasil penelitian ini dapat digunakan sebagai data dasar untuk acuan dan pedoman dalam melakukan penelitian selanjutnya dengan penambahan jumlah variabel dan sub variabel yang belum diteliti dalam penelitian ini.
\end{abstract}

Keywords:

Mother's knowledge,

reproductive health, puberty

Info Artikel

Tanggal dikirim: 6 Juni 2020

Tanggal direvisi: 20 Juli 2020

Tanggal diterima: 24 Juli 2020

DOI Artikel:

10.36341/jomis.v4i2.1320

Creative Commons Attribution-

NonCommercial-ShareAlike

4.0 International License.

\begin{abstract}
Adolescence is a period of rapid growth and development, especially physical, psychological and intellectual. Teenagers have a characteristic that is a great sense of curiosity, likes adventure and challenges and tends to dare to bear the risk of his actions without being preceded by careful consideration. The role and contribution of mothers is very large in the period of seeing the development of their children to be able to pass through the period of puberty, because a mother who is more attentive and follows the development of each of her children. This study uses quantitative research with analytical methods and cross-sectional research designs, namely research to see the relationship between independent and dependent variables. The purpose of the study is to determine the relationship of maternal knowledge about adolescent reproductive health with efforts to prepare rnasapubertas in children at SD Negeri 20 Pekanbaru. The results of the study are there is a relationship between maternal knowledge about adolescent reproductive health with efforts to prepare for puberty in children in SD Negeri 20 Pckanbaru with a Pvalue - 0.027. It is expected that further researchers the results of this study can be used as basic data for reference and guidance in conducting further research by adding the number of variables and subvariables that have not been examined in this study.
\end{abstract}




\section{PENDAHULUAN}

Masa remaja adalah masa terjadinya pertumbuhan dan perkembangan yang cepat baik secara fisik, psikologis maupun intelektual. Remaja memiliki sifat yang khas yaitu mempunyai rasa keingintahuan yang besar, menyukai petualangan dan tantangan serta cenderung berani menanggung risiko atas perbuatannya tanpa didahului oleh pertimbangan yang matang. Jika remaja tidak tepat dalam mengambil keputusan saat menghadapi konflik, maka mereka akan jatuh kedalam prilaku yang bersiko dan bisa juga mereka menerima resiko jangka pendek dan jangka panjang terutama menyangkut masalah kesehatan fisik dan psikologis. Remaja dengan sifat dan prilaku yang berisko sangat memerlukan pelayanan kesehatan yang peduli remaja, tidak hanya itu saja pelayanan ini juga mampu memenuhi kebutuhan kesehatan remaja termasuk pelayanan kesehatan reproduksinya[1].

Ibu memiliki peran untuk memperhatikan perkembangan anaknya, hal ini sangat penting dalam membimbing dan menjadi tempat untuk bsa saling berbagi masalah bagi anak-anaknya. Karena kadang anak-anak menganggap membicarakan masalah puberitas kepada orang lain merupakan hal yang tabu. Untuk menimbulkan rasa nyaman bagi remaja dalam menceritakan masalah puberitasnya perlu pendekatan dan perhatian khusus dari orang tuanya. Memberikan pengarahan dan pendampingan kepada anak-anak yang beranjak remaja dalam menyikapi setiap perubahan semasa pubertas bertujuan agar tidak terjadinya peyimpangan prilaku remaja.

\section{TINJAUAN PUSTAKA}

Pengetahuan (knowledge) adalah hasil dari rasa keingintahuan manusia terhadap sesuatu dan hasrat untuk meningkatkan harkat hidup sehingga kehidupan menjadi lebih baik dan nyaman yang berkembang sebagai upaya untuk memenuhi kebutuhan manusia, baik di masa sekarang mau pun di masa depan. Pengetahuan hanya sekedar menjawab pertanyaan what, misalnya apa alam, apa manusia, apa air, dan lainnya[2].

Program kesehatan reproduksi remaja bertujuan memberikan pengetahuan yang memadai kepada anak sehingga diharapkan mampu menjalani masa remaja serta memelihara kesehatan dirinya guna memasuki masa kehidupan berkeluarga dengan reproduksi yang sehat [3]. Untuk itu peneliti tertatik melakukan penelitian dengan judul hubungan pengetahuan ibu tentang kesehatan reproduksi remaja dengan upaya mempersiapkan masa pubertas pada anak

Untuk membentuk tindakan seseorang Pengetahuan merupakan domain yang penting. Pengetahuan akan menyebabkan seseorang berperilaku sesuai pengetahuan yang dimilikinya. Sehingga dengan adanya pengetahuan ibu tentang kesehatan reproduksi remaja, maka akan timbul upaya mempersiapkan masa pubertas yang akan dialami anak mereka[4].

Pentingnya pengetahuan remaja tentang perubahan fisiknya karena masa remaja merupakan masa stress full karena ada perubahan fisik dan biologis serta perubahan tuntutan dari lingkungan, sehingga diperlukan suatu proses penyesuaian diri dari remaja. Ketidaktahuan remaja mengenai perubahan yang terjadi pada dirinya dapat menimbulkan rasa cemas dan malu. Mereka akan bertanyatanya apa yang harus mereka lakukan dengan perubahan itu[5].

Menurut sebagaian Orang Tua, seks hanya pantas dibicarakan secara pribadi oleh orang dewasa. Seks masih sangat tabu dan tidak lumrah untuk dibicarakan baik untuk anakanak maupun untuk remaja. Padahal perkembangan seksual pada remaja berlangsung paling cepat dari berbagai siklus kehidupan manusia, sehingga penting bagi remaja untuk mengetahui perkembangan seksual yang dihadapinya[6] .

BKKBN juga memiliki suatu program yang berfokus pada kesehatan reproduksi remaja dalam rangka menjamin pemenuhan hak seksual dan kesehatan reproduksi remaja, digunakan upaya terpadu guna mendapatkan 
informasi kesehatan reproduksi sedini mungkin pada remaja melalui Pusat Informasi dan Konseling Kesehatan Remaja (PIKKR) yang bertujuan untuk meningkatkan pengetahuan remaja tentang permasalahan kesehatan reproduksi[7]

\section{METODE}

Penelitian ini menggunakan jenis penelitian kuantitatif dengan metode analitik dan desain penelitian cross sectional yaitu penelitian untuk melihat hubungan variabel independen dan dependen sehingga diperoleh informasi tentang hubungan pengetahuan ibu tentang kesehatan reproduksi remaja dengan upaya mempersiapkan masa pubertas pada anak di SD Negeri 20 Pekanbaru.Sampel pada penelitian ini adalah sebagian orangtua murid kelas VI SD Negeri 20 Pekanbaru.Sampel dalam penelitian ini ditentukan dengan menggunakan rumus;

$$
\mathrm{n}=\frac{\mathrm{N}}{1+\mathrm{N}\left(\mathrm{d}^{2}\right)}
$$

Keterangan:

$\begin{array}{ll}\mathrm{N} & \text { : besar populasi } \\ \mathrm{n} & \text { : besar sampel } \\ \mathrm{d} & \text { : tingkat kesalahan yang masih } \\ & \text { diterima }(0,1)\end{array}$

analisis data menggunakan univariat dan bivariat. Analisa data dilakukan dengan alat bantu program Statistikal Product Service Solutions (SPSS)

\section{HASIL DAN PEMBAHASAN}

Setelah peneliti melakukan penelitian tentang hubungan pengetahuan ibu tentang kesehatan reproduksi remaja dengan upaya mempersiapkan masa pubertas pada anak di SD Negeri 20 Pekanbaru yang berlangsung sejak tanggal 26 November - 5 Desember 2018 dengan total responden sebanyak 58 orang, maka didapatkan hasil sebagai berikut:

\section{Analisa Univariat}

Mayoritas jenis kelamin anak adalah perempuan sebanyak 33 orang $(56,9 \%)$. Umur anak 11 tahun sebanyak 33 orang $(56,9 \%)$. Ibu tidak bekerja sebanyak 49 orang $(84,5 \%)$. Umur ibu 36 - 45 tahun sebanyak 46 orang
$(79,3 \%)$.

Tabel 4.1

Distribusi Frekuensi Pengetahuan Ibu tentang Kesehatan Reproduksi Remajadi SD Negeri 20 PekanbaruTahun 2018

\begin{tabular}{cccc}
\hline No & Pengetahuan & $\begin{array}{c}\text { Frekuensi } \\
(\mathbf{F})\end{array}$ & $\begin{array}{c}\text { Persentase } \\
(\mathbf{\%})\end{array}$ \\
\hline 1 & Baik & 35 & 60,3 \\
2 & Kurang & 23 & 39,7 \\
\hline & Jumlah & $\mathbf{5 8}$ & $\mathbf{1 0 0}$ \\
\hline
\end{tabular}

Dari tabel 4.1 dapat dilihat mayoritas pengetahuan ibu tentang kesehatan reproduksi remaja di SD Negeri 20 Pekanbaru Tahun 2018 adalah baik sebanyak 35 orang (60,3\%).

$\begin{array}{lcr} & \text { Tabel 4.2 } & \text { Upaya } \\ \text { Distribusi } & \text { Frekuensi } & \text { Upak } \\ \text { Mempersiapkan Masa Pubertas pada Anak } \\ \text { di SD Negeri 20 Pekanbaru }\end{array}$

\begin{tabular}{|c|c|c|c|}
\hline & Sikap & Frekuensi (F) & $\begin{array}{l}\text { Persentase } \\
(\%)\end{array}$ \\
\hline 1 & Baik & 38 & 65,5 \\
\hline 2 & Kurang & 20 & 34,5 \\
\hline \multicolumn{2}{|r|}{ Jumlah } & 58 & 100 \\
\hline
\end{tabular}

Dari tabel 4.2 dapat dilihat mayoritas upaya mempersiapkan masa pubertas pada anak di SD Negeri 20 Pekanbaru adalah baik sebanyak 38 orang $(65,5 \%)$

\section{Analisa Bivariat}

Hasil analisa bivariat, 35 responden yang berpengetahuan baik tentang kesehatan reproduksi remaja, 27 orang $(77,1 \%)$ sudah baik dalam upaya mempersiapkan masa pubertas pada anak, dan 8 orang $(39,1 \%)$ dalam upaya mempersiapkan masa pubertas pada anak. Sedangkan dari 23 responden yangberpengetahuan kurang, 11 orang $(47,0 \%)$ sudah baik dalam upaya mempersiapkan masa pubertas pada anak, dan 12 orang $(52,5 \%)$ kurang dalam upaya mempersiapkan masa pubertas pada anak. Berdasarkan hasil uji statistik diperoleh nilai $\mathrm{P}_{\text {value }}=0,027$, maka 
dapat disimpulkan bahwa terdapat hubungan pengetahuan ibu tentang kesehatan reproduksi remaja dengan upaya mempersiapkan masa pubertas pada anak di SD Negeri 20 Pekanbaru.

Berdasarkan hasil uji statistik diperoleh $\mathrm{P}_{\text {value }}=0,027$ terdapat hubungan yang bermakna secara statistik $(\mathrm{p}<0,05)$ artinya ada hubungan pengetahuan ibu tentang kesehatan reproduksi remaja dengan upaya mempersiapkan masa pubertas pada anaknya. Hal ini menunjukkan bahwa dengan meningkatnya pengetahuan ibu tentang kesehatan reproduksi remaja bersamaan dengan faktor-faktor lain yang berpengaruh, seperti halnya karakteristik ibu dapat meningkatkan upaya mempersiapkan masa pubertas pada anaknya.Peningkatan variabel pengetahuan ibu saja tanpa ada upaya meningkatkan variabel yang berpengaruh tidak akan secara mutlak meningkatkan upaya ibu dalam mempersiapkan masa pubertas anaknya.

Hasil penelitian mengenai crosstabulation responden berdasarkan pengetahuan tentang kesehatan reproduksi remaja dan upaya mempersiapkan masa pubertas pada anak dapat dilihat bahwa ada 23 responden yang mempunyai pengetahuan kurang mengenai kesehatan reproduksi pada remaja menunjukkan upaya yang baik dalam mempersiapkan masa pubertas anaknya. Hal ini dimungkinkan karena seseorang telah memiliki pengalaman mengenai pubertas dan bagaimana menghadapi masa pubertas serta adanya pengaruh orang lain yang memberikan informasi mengenai pubertas dengan benar. Sesuai dengan pendapat Middlebrook bahwa pengaruh orang lain yang memberikan informasi dengan benar akan mendorong seseorang untuk bersikap positif. Hasil penelitian ini juga dapat dilihat bahwa ada 38 responden dengan pengetahuan baik mengenai kesehatan reproduksi pada remaja mempunyai upaya yang kurang dalam persiapan masa pubertas pada anaknya. Hal ini dapat dimungkinkan karena adanya pengaruh kebudayaan dan pengaruh orang lain yang memberikan informasi mengenai kesehatan reproduksi kurang tepat. Pengaruh terbesar pembentukan sikap manusia adalah dari dibesarkannya kebudayaan di kehidupan kita. Selain itu, menurut Mu'tadin usaha orang tua dalam mempersiapkan masa pubertas pada anak dipengaruhi oleh faktor kebudayaan. Memberikan informasi tentang kesehatan reproduksi pada anak sejak dini merupakan hal yang tidak biasa dilakukan orang tua, banyak orang tua yang beranggapan seperti ini.

Berbagai perubahan di dalam tubuh akan dialami oleh seorang anak selama masa pubertasnya. Perubahan tersebut akan cenderung menjadi pengalaman yang traumatis, jika tidak dipersiapkan sejak dini. Peran orangtua khususnya ibu, mempunyai sangat penting dalam membekali anak untuk menghadapi fase remaja, sehingga dibutuhkan pengetahuan yang cukup dari ibu. Penelitian ini sesuai dengan [8].

Hasil penelitian ini sejalan dengan penelitian[9], tentang Hubungan Pengetahuan Ibu Tentang Kesehatan Reproduksi Remaja Dengan Upaya Mempersiapkan Masa Pubertas Pada Anak mayoritas responden mempunyai pengetahuan yang tinggi tentang kesehatan reproduksi remaja yaitu 86 ibu $(63,7 \%)$. Mayoritas repsonden mempunyai upaya yang baik dalam mempersiapkan masa pubertas pada anak yaitu 79 ibu $(58,5 \%)$. Hasil analisis Kendal Tau yaitu nilai significancy (p) sebesar $0,000 \quad(\mathrm{p}<0,05)$ dengan nilai korelasi (r) sebesar 0,663. Kesimpulan: Terdapat hubungan yang bermakna antara pengetahuan ibu tentang kesehatan reproduksi remaja dengan upaya mempersiapkan masa pubertas pada anak, dengen arah korelasi positif dengan kekuatan korelasi kuat. 
Hasil penelitian ini juga sejalan dengan penelitian[10],dengan judul Hubungan Pengetahuan Remaja Putri Tentang Kesehatan Reproduksi Remaja Dengan Kesiapan Menghadapi Masa Pubertas Di Desa Pertumbuken Kecamatan Barusjahe Kabupaten Karo Tahun 2015. Hasil penelitian yaitu Hasil analisa didapatkan bahwa remaja putri dengan pengetahuan baik sebanyak 2 $(6,7 \%)$ yang memiliki berpengetahuan cukup sebanyak $15(50 \%)$ dan yang memiliki pengetahuan kurang sebanyak 13 (43,3\%) hasil uji statistik Chi-Square diperoleh $\rho=$ 0,003 yang berarti ada hubungan kesehatan reproduksi remaja dengan kesiapan menghadapi masa pubertas.

Penelitian ini sejalan dengan hasil penelitian yang dilakukan oleh[11], tentang Hubungan antara Pengetahuan Ibu tentang Kesehatan Reproduksi Remaja dengan Upaya Mempersiapkan Masa Pubertas pada Anak. Hasil penelitian berdasarkan data karakteristik menunjukkan sebagian besar responden yang memiliki umur antara 31-40 tahun sebanyak $57 \%$.

Pengetahuan merupakan hasil tahu, dan ini terjadi setelah orang melakukan pengindraan terhadap obyek tertentu. Pengindraan panca indera manusia yaitu indera penglihatan, pendengaran, penciuman, rasa dan raba[12]. Pengetahuan berhubungan erat dengan ibu, ibu yang memiliki pengetahuan yang cukup akan cenderung lebih tenang dalam mempersiapkan masa pubertas anaknya. Berbeda dengan ibu yang memiliki pengetahuan yang kurang, dia akan merasa gelisah dalam mempersiapkan masa pubertas anaknya[13].

Hasil penelitian ini sesuai dengan penelitian yang dilakukan oleh[14] yaitu Hubungan Umur, Pendidikan, Dan Pengetahuan Ibu Dengan Upaya Mempersiapkan Masa Pubertas Pada Remaja Di Rt 48 Kelurahan 3-4 Ulu Palembang Tahun 2018. Hasil penelitian Hasil penelitan pada variabel umur, pendidikan, dan pengetahuan masing-masing terdapat hubungan dengan upaya mempersiapkan masa pubertas pada anak dengan hasil pvalue $0,030<\alpha 0,05$ untuk umur, pvalue $0,014<\alpha 0,05$ untuk pendidikan, dan pvalue $0,002<\alpha 0,05$ untuk pengetahuan.

Penelitian ini sejalan dengan penelitian[15], dengan hasil penelitian berdasarkan hasil uji chi square menunjukkan ada hubungan tingkat pengetahuan ibu tentang kesehatan reproduksi

remaja dengan kesiapan anak menghadapi masa pubertas. Hasil uji statistik dengan menggunakan chi square diperoleh $\rho$ value $0,021<0,05$.

Berdasarkan hasil penelitian dan uraian teori di atas menurut analisis peneliti pada dasarnya adanya perubahan pengetahuan yang dimiliki seseorang dari tidak tahu menjadi tahu dan semakin mengerti khususnya dalam hal pengetahuan tentang kesehatan reproduksi remaja. Pengetahuan yang dimiliki ibu tentang kesehatan reproduksi remaja berhubungan dengan kesiapan anak menghadapi masa pubertas. Semakin tinggi tingkat pengetahuan ibu yang diperoleh maka kesiapan menghadapi masa pubertas remaja akan semakin mantap dan remaja tidak akan lagi merasa dirinya kotor atau berpikiran negatif tentang perubahan pubertas yang dialaminya

\section{KESIMPULAN}

Berdasarkan hasil penelitian tentang hubungan pengetahuan ibu tentang kesehatan reproduksi remaja dengan upaya mempersiapkan masa pubertas pada anak di SD Negeri 20 Pekanbaru sehingga dapat ditarik kesimpulan sebagai berikut: Mayoritas jenis kelamin anak adalah perempuan sebanyak 33 orang $(56,9 \%)$. Umur anak 11 tahun sebanyak 33 orang $(46,9 \%)$. Ibu tidak bekerja sebanyak 49 orang $(84,5 \%)$. Umur ibu 36 - 45 tahun sebanyak 46 orang $(79,3 \%)$. Mayoritas pengetahuan ibu tentang kesehatan reproduksi remaja di SD Negeri 20 Pekanbaru Tahun 2018 adalah baik sebanyak 35 orang (60,3\%).Mayoritas upaya mempersiapkan masa pubertas pada anak di SD Negeri 20 Pekanbaru adalah baik sebanyak 38 orang $(65,5 \%)$ Terdapat hubungan pengetahuan ibu tentang kesehatan reproduksi remaja dengan upaya mempersiapkan masa pubertas pada anak di SD Negeri 20 Pekanbaru dengan $\mathrm{P}_{\text {value }}$ 
$=0,027$.

\section{DAFTAR PUSTAKA}

[1] Kemenkes RI, Infodatin: Situasi Kesehatan Reproduksi Remaja. Jakarta: Pusat Data dan Informasi Kementerian Kesehatan Republik Indonesia, 2015.

[2] A. P. Ariani, Aplikasi Metodologi Penelitian Kebidanan dan Kesehatan Reproduksi. Yogyakarta: Nuha medika, 2014.

[3] H. Z. Janiwarty, B dan Pieter, Pendidikan Psikologi untuk Bidan Suatu Teori dan Terapannya. Yogyakarta: Rapha Publishing, 2013.

[4] S. Notoatmodjo, . Pengantar Pendidikan Kesehatan dan Ilmu Perilaku Kesehatan. Jakarta: Rineka Cipta, 2012.

[5] E. Liberty, "Karya Tulis Ilmiah, Program Studi Diploma III Kebidanan," Sekolah Tinggi Ilmu Kesehatan Kusuma Husada. Surakarta, 2013.

[6] I. Khalis, Selain Nikmat Seks itu Sangat Menyehatkan. Yogyakarta: DIVA Press, 2011.

[7] E. Kusmiran, Kesehatan Reproduksi Remaja Dan Wanita. Jakarta: salemba medika, 2011.

[8] K. Agnes Candra Dewi, "Hubungan Antara Pengetahuan Ibu Tentang Kesehatan Reproduksi Remaja Dengan Upaya Mempersiapkan Masa Pubertas Pada Anak," Gaster, vol. 9, pp. 17-25, 2012.

[9] D. Saptowati, "Hubungan Pengetahuan Ibu Tentang Kesehatan Reproduksi Remaja Dengan Upaya Mempersiapkan Masa Pubertas Pada Anak," UNS-Fak. Kedokteran Program Studi DIV Bidan Pendidik, 2014.

[10] Harry Dito Meliala, "Hubungan Pengetahuan Remaja Putri Tentang Kesehatan Reproduksi Remaja Dengan Kesiapan Menghadapi Masa Pubertas Di Desa Pertumbuken Kecamatan Barusjahe Kabupaten Karo Tahun 2015," Wahana Inov., vol. 5, pp. 460-
465, 2016.

[11] Dewi dan Kamida, "Hubungan antara Pengetahuan Ibu tentang Kesehatan Reproduksi Remaja dengan Upaya Mempersiapkan Masa Pubertas pada Anak," Gaster, vol. 9, pp. 17-25, 2012.

[12] dkk Savitri, Kesehatan Reproduksi Remaja. Yogyakarta: pustaka baru press, 2015.

[13] T. Lestari, Kumpulan Teori untuk Kajian Pustaka Penelitian Kesehatan. Yogyakarta: Nuha medika, 2015.

[14] A. Pratiwi, "Hubungan Umur, Pendidikan, Dan Pengetahuan Ibu Dengan Upaya Mempersiapkan Masa Pubertas Pada Remaja Di Rt 48 Kelurahan 3-4 Ulu Palembang Tahun 2018," J. Kesehat. Saelmakers Perdana, vol. 2, pp. 63-70, 2018.

[15] Budiati dan Apriastuti, "Hubungan Tingkat Pengetahuan Ibu tentang Kesehatan Reproduksi Remaja dengan Keseiapan Anak Menghadapi masa Pubertas," J. Kebidanan, vol. 4, pp. 96101, 2012. 